\title{
ORGANOCHLORINE INSECTICIDES RESIDUES IN RAW COW'S MILK, CREAM AND BUTTER FROM BENI-SUEF GOVERNORATE
}

\author{
G.M. HASSAN ${ }^{1}$; SAADIA H.E. ${ }^{2}$; A. REFAEE ${ }^{3}$ and M. RABEE ${ }^{4}$ \\ ${ }^{1,2}$ Food Hygiene Department, Fac. Vet. Med., Beni-Suef University \\ ${ }^{3,4}$ Cemistry Department, Animal Health Research Institute \\ Received: 18 August 2016; $\quad$ Accepted: 30 August 2016
}

\begin{abstract}
Organochlorine insecticides residues $(\alpha-\mathrm{HCH}, \beta-\mathrm{HCH}$, Lindane, HCB, Aldrin, Heptachlor, Chlordane, total DDT, Endrin and Methoxychlor) were analyzed in 75 samples of raw milk, sour cream and cooking buttercollected from Beni-Suef Governorate- using gas chromatography with electron capture detector (GC-ECD). The results indicated that all the examined samples were accepted except three butter samples showed residue levels exceeded the Maximum Residues Levels (MRLs).
\end{abstract}

Key words: Organochlorine insecticides, milk, cream, butter, gas chromatography

\section{INTRODUCTION}

Milk is considered as an early complete food since it is a good source for protein, fat and major minerals. Also, milk is the main constituent of the daily diet, especially for vulnerable groups such infants, schoolage children and old age (Kampire et al., 2011).

Milk and milk products are subjected to many persistent environmental contaminants such as organochlorine insecticides and their metabolites. Organochlorine insecticides are highly stable under normal environmental conditions, bio accumulate through food chain and readily excreted in the milk fat due to lipophilic property (Mukherjee and Gobal, 1993 and Aman and Bluthgen, 1997).

The environmental pollution with organochlorine insecticides has decreased due to banning of these compounds, however, several recent reports (Aksoy et al., 2013; Ranganathan et al., 2014; Kotinagu and Krishnaiah, 2015) indicate that pollution with organochlorines still present and may be of public and environmental health significance.

The contamination of milk and its products with organochlorine insecticides and their metabolites have been recorded in different countries. In Egypt,

Corresponding author: Dr. G.M. HASSAN

E-mail address:gamalhassen2000@yahoo.com

Present address:Food Hygiene Department, Fac. Vet. Med., BeniSuef University. although the use of organochlorine pesticides had been banned since 1985, these chemicals were found in milk and milk products from some localities (ElTalawy, 2010; Shaker and El-sharkawy, 2015).

Organochlorine insecticides are a source of several mysterious diseases through chronic toxicity and sub lethal exposure. These diseases include cancer, liver and kidney dysfunction, growth depression and neuritis (Schuh et al., 2009; El Amine et al., 2013 and Wilson et al., 2014). Therefore, there is need for monitoring levels of OCP residues in milk and milk products so this work was carried out to investigate the extent of contamination of milk, cream and butter with 10 Organochlorine insecticides and to assess human exposure to OCPs through the consumption of these products.

\section{MATERIALS AND METHOD}

The method of Heck et al. (2007) was adopted.

\section{A- Collection of samples:}

A total of 75 random samples including raw cow's milk, sour cream and cooking butter ( 25 of each) were collected from different districts at Beni-Suef Governorate, Egypt, during the period from September 2014 to June 2015. and transported in cooling boxes containing ice bags to the laboratory of Animal Health Research Institute where they were immediately stored in a freezer at $-20{ }^{\circ} \mathrm{C}$ until further analysis.

\section{B- Sample extraction:}

1) Milk samples: The samples were thawed, homogenized and mixed thoroughly. $50 \mathrm{ml}$ of each 
sample centrifuged for $15 \mathrm{~min}$, at $5000 \mathrm{rpm}$ to obtain milk fat. Anhydrous sodium sulfate $(25 \mathrm{~g})$ was mixed with one gram milk fat in a $250 \mathrm{ml}$ flask. To this mixture $100 \mathrm{ml}$ of petroleum ether were added with vigorous shaking for $2 \mathrm{~min}$. It was then allowed to settle down and the petroleum ether was filtered off into another flask through a glass funnel containing anhydrous sodium sulfate on top of glass wool to remove any traces of water. The filtered extract was evaporated to near dryness using a rotatory evaporator and concentrated to about $1 \mathrm{ml}$ which was taken up in $3 \mathrm{ml}$ of hexane and kept in a flask for the clean-up with $100 \mathrm{ml}$ of hexane to extract organochlorine insecticides.

\section{2) Cream samples:}

$100 \mathrm{ml}$ of well mixed cream sample were centrifuged at $5000 \mathrm{rpm}$ for $15 \mathrm{~min}$. The upper layer composed of fat was removed and placed in a small clean beaker from which $1 \mathrm{~g}$ of fat was weighed out for extraction as mentioned before.

2) Butter samples: $100 \mathrm{~g}$ of butter sample were warmed to about $50^{\circ} \mathrm{C}$ until fat separated and decanted through dry filter paper No. 10, then $1 \mathrm{~g}$ was weighed out for extraction as mentioned before.

\section{C- Gas Chromatography analysis:}

Agilent GC Model $6890 \mathrm{~N}$ equipped with an $\mathrm{Ni}^{63}$ electron capture detector was used.

\section{RESULTS}

Table 1: Residues of organochlorine insecticides in milk samples (mg/kg)

\begin{tabular}{|c|c|c|c|c|c|}
\hline Insecticide & Min. (mg/kg) & $\begin{array}{l}\text { (mg/kg) } \\
\text { Max. }\end{array}$ & Mean $(\mathrm{mg} / \mathrm{kg}) \pm \mathrm{SE}$ & $\begin{array}{c}\% \text { of +ve } \\
\text { results }\end{array}$ & $\begin{array}{c}\text { Samples exceed } \\
\text { MRL }\end{array}$ \\
\hline$\alpha-H C H$ & 0 & 0.000012 & $0.0000005 \pm 0.0000005$ & 4 & 0 \\
\hline$\beta-\mathbf{H C H}$ & 0 & 0.0006 & $0.00006 \pm 0.00003$ & 20 & 0 \\
\hline $\begin{array}{c}\gamma-\mathrm{HCH} \\
\text { (Lindane) }\end{array}$ & 0 & 0.00006 & $0.000007 \pm 0.0000034$ & 16 & 0 \\
\hline HCB & 0 & 0 & 0 & 0 & 0 \\
\hline Aldrin & 0 & 0.00016 & $0.000052 \pm 0.00001$ & 68 & 0 \\
\hline Heptachlor & 0 & 0.00022 & $0.00001112 \pm 0.000009$ & 24 & 0 \\
\hline Chlordane & 0 & 0.00014 & $0.000012 \pm 0.000006$ & 28 & 0 \\
\hline total DDT & 0 & 0.0005 & $0.000055 \pm 0.00003$ & 35 & 0 \\
\hline Endrine & 0 & 0.00012 & $0.000009 \pm 0.000006$ & 10 & 0 \\
\hline Methoxychlor & 0 & 0.001 & $0.00004 \pm 0.00004$ & 4 & 0 \\
\hline
\end{tabular}


Table 2: Residues of organochlorine insecticides in cream samples (mg/kg)

\begin{tabular}{cccccc}
\hline Insecticide & Min. (mg/kg) & Max. $(\mathbf{m g} / \mathbf{k g})$ & Mean $(\mathbf{m g} / \mathbf{k g}) \pm$ SE & $\begin{array}{c}\text { \% of +ve } \\
\text { results }\end{array}$ & $\begin{array}{c}\text { Samples exceed } \\
\text { MRL }\end{array}$ \\
\hline $\boldsymbol{\alpha}$-HCH & 0 & 0.0000006 & $0.0024 \mathrm{E}-05 \pm 0.0024 \mathrm{E}-05$ & 4 & 0 \\
\hline $\boldsymbol{\beta}$ - HCH & 0 & 0.0002 & $0.000012 \pm 0.000008$ & 12 & 0 \\
\hline $\boldsymbol{\gamma}$-HCH & 0 & 0 & 0 & 0 & 0 \\
\hline HCB & 0 & 0.00002 & $0.00000096 \pm 0.0000008$ & 8 & 0 \\
\hline Aldrin & 0 & 0.00001 & $0.0000017 \pm 0.000000056$ & 36 & 0 \\
\hline Heptachlor & 0 & 0 & 0 & 0 & 0 \\
\hline Chlordane & 0 & 0.00004 & $0.000002 \pm 0.0000016$ & 12 & 0 \\
\hline total DDT & 0 & 0.0004 & $0.00003 \pm 0.000017$ & 52 & 0 \\
\hline Endrine & 0 & 0.00016 & $0.00001 \pm 0.000006$ & 28 & 0 \\
\hline Methoxychlor & 0 & 0.00018 & $0.00001 \pm 0.000007$ & 8 & 0 \\
\hline
\end{tabular}

Table 3: Residues of organochlorine insecticides in butter samples (mg/kg)

\begin{tabular}{|c|c|c|c|c|c|}
\hline Insecticide & Min. (mg/kg) & Max. (mg/kg) & Mean $(\mathrm{mg} / \mathrm{kg}) \pm \mathrm{SE}$ & $\%$ of +ve results & $\begin{array}{c}\text { Samples } \\
\text { exceed MRL }\end{array}$ \\
\hline$\alpha-\mathbf{H C H}$ & 0 & 0 & 0 & 0 & 0 \\
\hline$\beta-\mathbf{H C H}$ & 0 & 0.001 & $0.00004 \pm 0.00004$ & 4 & 1 \\
\hline$\gamma-\mathrm{HCH}$ & 0 & 0.07 & $0.0049 \pm 0.0034$ & 8 & 2 \\
\hline HCB & 0 & 0 & 0 & 0 & 0 \\
\hline Aldrin & 0 & 0.00016 & $0.000007 \pm 0.000006$ & 20 & 0 \\
\hline Heptachlor & 0 & 0.0002 & $0.00004 \pm 0.000008$ & 4 & 0 \\
\hline Chlordane & 0 & 0.00016 & $0.000006 \pm 0.000008$ & 16 & 0 \\
\hline total DDT & 0 & 0.0022 & $0.0001 \pm 0.000087$ & 36 & 0 \\
\hline Endrine & 0 & 0.00008 & $0.000005 \pm 0.000003$ & 16 & 0 \\
\hline Methoxychlor & 0 & 0 & 0 & 0 & 0 \\
\hline
\end{tabular}


Table 4: Calculated ADI and HQ for mean values of organochlorine insecticide residues in milk samples (mg/kg b.w)

\begin{tabular}{cccc}
\hline Insecticide & ADI (mg / 70 kg person) & $\begin{array}{c}\text { Calculated mean value (200 } \\
\text { ml milk) }\end{array}$ & HQ \\
\hline $\boldsymbol{\alpha}$-HCH & 0.07 & 0.000000003 & 0.00000004 \\
\hline $\boldsymbol{\beta}$ - HCH & 0.021 & 0.00000036 & 0.000017 \\
\hline $\boldsymbol{\gamma}$-HCH & 0.35 & 0.000000004 & 0.0000001 \\
\hline HCB & 0.042 & 0 & 0.000045 \\
\hline Aldrin & 0.007 & 0.0000003 & 0.00001 \\
\hline Heptachlor & 0.007 & 0.000000067 & 0.000002 \\
\hline Chlordane & 0.035 & 0.00000007 & 0.00000047 \\
\hline Endal DDT & 0.7 & 0.0000003 & 0.000004 \\
\hline Methoxychlor & 0.014 & 0.000000005 & 0.000000034 \\
\hline
\end{tabular}

Table 5: Calculated ADI and HQ for mean values of organochlorine insecticide residues in cream samples (mg/kg b.w)

\begin{tabular}{cccc}
\hline Insecticide & $\begin{array}{c}\text { ADI } \mathbf{~ m g} / \mathbf{7 0} \mathbf{~ k g} \\
\text { person }\end{array}$ & $\begin{array}{c}\text { Calculated mean value } \\
(\mathbf{1 0 0} \text { gm cream })\end{array}$ & HQ \\
\hline $\boldsymbol{\alpha}$-HCH & 0.07 & 0.000000001 & 0.000000015 \\
\hline $\boldsymbol{\beta}$ - HCH & 0.021 & 0.00000054 & 0.000026 \\
\hline $\boldsymbol{\gamma}$-HCH & 0.35 & 0 & 0 \\
\hline HCB & 0.042 & 0.000000043 & 0.000001 \\
\hline Aldrin & 0.007 & 0.000000076 & 0.00001 \\
\hline Heptachlor & 0.007 & 0 & 0.0000025 \\
\hline Chlordane & 0.035 & 0.00000009 & 0.000002 \\
\hline total DDT & 0.7 & 0.00000135 & 0.00003 \\
\hline Endrine & 0.014 & 0.00000045 & 0.00000006 \\
\hline Methoxychlor & 7 & 0.00000045 &
\end{tabular}


Table 6: Calculated ADI and HQ for mean values of organochlorine insecticide residues in butter samples (mg/kg b.w)

\begin{tabular}{cccc}
\hline Insecticide & $\begin{array}{c}\text { ADI (mg / 70 kg } \\
\text { person) }\end{array}$ & $\begin{array}{c}\text { Calculated mean value (8 } \\
\text { gm butter) }\end{array}$ & HQ \\
\hline $\boldsymbol{\alpha}$-HCH & 0.07 & 0 & 0 \\
\hline $\boldsymbol{\beta}$ - HCH & 0.021 & 0.00000032 & 0.00002 \\
\hline $\boldsymbol{\gamma}$-HCH & 0.35 & 0.00004 & 0.0001 \\
\hline HCB & 0.042 & 0 & 0 \\
\hline Aldrin & 0.007 & 0.00000006 & 0.000009 \\
\hline Heptachlor & 0.007 & 0.0000003 & 0.00004 \\
\hline Chlordane & 0.035 & 0.00000006 & 0.0000018 \\
\hline total DDT & 0.7 & 0.0000008 & 0.000001 \\
\hline Endrine & 0.014 & 0.00000004 & 0.000003 \\
\hline Methoxychlor & 7 & 0 & 0 \\
\hline
\end{tabular}

\section{DISCUSSION}

From the results recorded in Table (1) it is cleared that 9 organochlorine insecticides were detected including $\alpha-\mathrm{HCH}, \quad \beta-\mathrm{HCH}, \quad \gamma-\mathrm{HCH}, \quad$ Aldrin, Heptachlor, Chlordane, total DDT, Endrin and Methoxychlor at percentages of $4,20,16,68,24$, $28,35,10$ and $4 \%$ respectively, and with mean values of $0.0000005 \pm 0.0000005,0.00006 \pm$ $0.00003, \quad 0.000007 \pm 0.0000034, \quad 0.000052 \pm$ $0.00001, \quad 0.00001112 \pm 0.000009, \quad 0.000012 \pm$ $0.000006, \quad 0.000055 \pm 0.00003, \quad 0.000009 \pm$ 0.000006 and $0.00004 \pm 0.00004(\mathrm{mg} / \mathrm{kg})$ on fat basis, respectively, while $\mathrm{HCB}$ could not be detected.21 (84\%) samples were contaminated with one or more of the residues. Aldrin was the most frequently detected insecticide, while $\alpha-\mathrm{HCH}$ and Methoxychlor had the least incidence.

The obtained data indicated the presence of organochlorine insecticides although stop use of such compounds since 1985 . It may be due to their environmental persistence that induced by the Chlorine content of these insecticides which makes the molecules more resistant to enzymatic degradation by bacteria, insects, and mammals and this property has the effect of reducing biodegradability and prolonging the residence time of these compounds in the environment (Ruth Stringer and Paul Johnston, 2002). The carbon-chlorine bond is very stable towards hydrolysis and, the greater the number of chlorinesubstitutions and/or functional groups, the greater the resistance to biological and photolyticdegradation. Chlorine attached to an aromatic (benzene) ring is more stable to hydrolysis than chlorine in aliphatic structures. As a result, organochlorine insecticides are typically ring structures with a chain or a branched chain framework (Joe Thornton, 2000) which prolonged their environmental persistence.

The presence of organochlorine insecticides at such low levels indicates the effectiveness of regulatory actions adopted for organochlorine insecticides in Egypt. However, the resistance of such compounds to breakdown leads to their presence in the environment. In the body of the animals, the metabolism and excretion of organochlorine insecticides residues are slow and finally deposited in the body fat or excreted in the milk.

Higher levels of organochlorine insecticide residues were obtained by Darko and Acquaah (2008); Salem et al. (2009); Kampire et al. (2011); Bulut et al. (2011); Avancini et al. (2012) and Gutterrez et al. (2013), while local studies in Egypt applied by Ahmed and Zaki (2009) detected $\alpha-\mathrm{HCH}, \beta-\mathrm{HCH}$, $\gamma-\mathrm{HCH}$, Heptachlor, Aldrin, Chlordane, Endrin and DDT at mean values of $0.003 \pm 0.0001,0.003 \pm$ $0.0002,0.002 \pm 0.000005,0.003 \pm 0.0001,0.004 \pm$ $0.000009,0.001 \pm 0.0001,0.0003 \pm 0.000005$ and $0.002 \pm 0.0007 \mathrm{mg} / \mathrm{kg}$, respectively. While Abd ElAziz (2005) detected only DDT at mean value of $0.0027 \pm 0.0001 \mathrm{mg} / \mathrm{kg}$.

On contrast, lower levels of some organochlorine insecticide residues were obtained by Darko and 
Acquaah (2008); Bulut et al. (2011) and Abd ElAziz (2005) who could not detect Lindane or Heptachlor. The low levels or undetected residues may be attributed to unuse of these insecticides or their presence was at levels less than the limit of detection. For quantitative risk assessment we calculated Hazard Quotient (HQ) (the risk to a human receptor from being exposed to a chemical via a single pathway) CCME (1996)

HQ

Estimated Dose $(\mu \mathrm{g} / \mathrm{kg} /$ day $)$

Tolerable Daily Intake $(\mu \mathrm{g} / \mathrm{kg} /$ day $)$

and the mean daily intake and from Table (4) we noticed that HQ and the calculated mean values (mg $170 \mathrm{~kg}$ person) from consumption of $200 \mathrm{ml}$ milk/day for $\alpha-\mathrm{HCH}, \quad \beta-\mathrm{HCH}, \quad \gamma-\mathrm{HCH}, \mathrm{HCB}, \quad$ Aldrin, Heptachlor, Chlordane, total DDT, Endrin and Methoxychlor were 0.00000004 and 0.000000003 , 0.000017 and $0.00000036,0.0000001$ and $0.00000004,0$ and $0,0.000045$ and 0.0000003 , 0.00001 and $0.000000067,0.000002$ and $0.00000007,0.00000047$ and $0.0000003,0.000004$ and 0.00000005 and 0.000000034 and 0.00000024 and we noticed that none of the obtained results exceeded 0.2 for HQ that indicated safety results according to CCME (1996) and also none of the obtained results exceeded the Acceptable daily Intake (ADI) of $0.07,0.021,0.35,0.042,0.007$, $0.007,0.035,0.7,0.014$ and $7 \mathrm{mg} / 70 \mathrm{~kg}$ person for $\alpha-\mathrm{HCH}, \beta-\mathrm{HCH}, \gamma-\mathrm{HCH}, \mathrm{HCB}$, Aldrin, Heptachlor, Chlordane, total DDT, Endrin and Methoxychlor, respectively, recommended by Codex Alimentarius Commission (2014).

Comparing our results with the Maximum Residues Levels (MRLs) adopted by Codex Alimentarius Commission (2014) that reported MRLs of $\alpha-\mathrm{HCH}$, $\beta-\mathrm{HCH}, \gamma-\mathrm{HCH}$, Aldrin, Heptachlor, Chlordane, total DDT, Endrin and Methoxychlor as 0.008, 0.0006, $0.01,0.006,0.006,0.002,0.02,0.0008$ and 0.005 $\mathrm{mg} / \mathrm{kg}$, respectively, it cleared that all the examined samples were below the MRLs and we found that these results were nearly similar to those recorded by Darko and Acquaah (2008) for (Aldrin and Lindane), Salem et al. (2009) for aldrine and Gutterrez et al. (2013) for $\alpha-\mathrm{HCH}, \beta-\mathrm{HCH}, \gamma-\mathrm{HCH}$, Heptachlor, Aldrin, Endrine and DDT in Mexico.

On contrast, other studies detected some organochlorine insecticide residues at levels exceeded the recommended MRL for one or more of the examined residues that may be due to illegal usage of such organochlorine insecticides during these periods or their usage were prohibited just from few years before the time of the study or excessive usage in past which with the bio accumulation and persistent nature of these chemicals lead to presence of one or more of the examined residues at high level.

From the results recorded in Table (2) it cleared that eight organochlorine insecticides were detected in the examined cream samples which were $\alpha-\mathrm{HCH}, \beta$ $\mathrm{HCH}, \mathrm{HCB}$, Aldrin, Chlordane, total DDT, Endrin and Methoxychlor at percentages of 4, 12, 8, 36, 12, 52,28 and $8 \%$, respectively, and with mean values of $0.0024 \mathrm{E}-05 \pm 0.0024 \mathrm{E}-05,0.000012 \pm 0.000008$, $0.00000096 \pm 0.0000008,0.0000017 \pm 0.000000056$, $0.000002 \pm 0.0000016,0.00003 \pm 0.000017,0.00001$ \pm 0.000006 and $0.00001 \pm 0.000007 \mathrm{mg} / \mathrm{kg}$ respectively. $19(76 \%)$ samples were contaminated with one or more of these residues.

Comparing the obtained results with MRLs adopted by Codex Alimentarius Commission (2014), we found that all the detected values were below the recommended MRLs and these findings were nearly similar to the results obtained by Ranganathan Y. et al. (2014).

On contrast, other studies detected some organochlorine insecticide residues at levels exceeded the recommended MRL for one or more of the examined residues. In Uzbekistan Muntean et al. (2003) detected $\alpha-\mathrm{HCH}$ and $\beta-\mathrm{HCH}$ at mean values of 0.03 and $0.045 \mathrm{mg} / \mathrm{kg}$ which exceeded the MRL for each component. In Romania Chiş et al. (2008) found that the $\mathrm{HCH}$ group ( $\beta$ and $\gamma$ isomers) appeared in all samples except $\alpha-\mathrm{HCH}$ isomer appeared in a single test, while Endosulphane, Endrin and DDT appeared randomly. All detected values of organochlorine insecticides were below MRL except one sample for Endrin (0.0966 ppm). In Gharbia, Egypt, El-Talawy (2010) found that $40 \%$ of the examined cream samples were contaminated with Endrin with average concentration of $102.07 \pm 12.42 \mathrm{ppb}$ and about $13.5 \%$ of the examined sour cream samples were unaccepted as the residues exceeded the MRLs recommended by Codex Alimentarius Commission (2004).

The results recorded in Table (5) revealed that HQ and the calculated mean values from consumption of $100 \mathrm{~g}$ cream /day for $\alpha-\mathrm{HCH}, \beta-\mathrm{HCH}, \gamma-\mathrm{HCH}$, HCB, Aldrin, Heptachlor, Chlordane, total DDT, Endrin and Methoxychlor were 0.000000015 and $0.000000001,0.000026$ and $0.00000054,0$ and 0 , 0.000001 and $0.000000043,0.00001$ and $0.000000076,0$ and $0,0.0000025$ and 0.00000009 , 0.000002 and $0.00000135,0.00003$ and 0.00000045 \& 0.00000006 and 0.00000045 , respectively, and it is cleared that none of the obtained results exceeded 0.2 for HQ that indicated safety results according to CCME(1996) and also none of the obtained results exceeded the ADI of $0.07,0.021,0.35,0.042,0.007$, $0.007,0.035,0.7,0.014$ and $7 \mathrm{mg} / 70 \mathrm{~kg}$ person for 
$\alpha-\mathrm{HCH}, \beta-\mathrm{HCH}, \gamma-\mathrm{HCH}, \mathrm{HCB}$, Aldrin, Heptachlor, Chlordane, total DDT, Endrin and Methoxychlor, respectively, as recommended by Codex Alimentarius Commission (2014).

From the results recorded in Table (3), it cleared that seven organochlorine insecticides were detected in the examined butter samples including $\beta-\mathrm{HCH}, \gamma$ $\mathrm{HCH}$, Aldrin, Heptachlor, Chlordane, total DDT and Endrin at percentages of 4, 8, 20, 4, 16, 36 and 16\%, respectively, and with mean values of $0.00004 \pm$ $0.00004,0.0049 \pm 0.0034,0.000007 \pm 0.000006$, $0.00004 \pm 0.000008,0.000008 \pm 0.000006,0.0001 \pm$ 0.000087 and $0.000005 \pm 0.000003 \mathrm{mg} \mathrm{kg}$, respectively. $10(40 \%)$ samples were contaminated with one or more of the residues. Higher levels of organochlorine insecticide residues were obtained by Waliszewski et al. (1997); Amr (1999); Pandit et al. (2002); Waliszewski et al. (2003); Abd El-Aziz (2005); Witczak and Abdel-Gawad (2014). In Turkey Aksoy et al. (2013) detected $\beta-\mathrm{HCH}$ in 3 of 88 samples at a mean level of $0.001 \mathrm{mg} / \mathrm{kg}$. Prachar et al. (1995) found that the examined butter samples from Slovakia were contaminated with $\mathrm{HCB}$ and DDT at mean values of 0.004 and $0.01 \mathrm{mg} / \mathrm{kg}$, respectively. Salem et al. (2009) in Jordan found DDT, $\beta-\mathrm{HCH}$ at incidence of 8 and $16 \%$, respectively, and at mean values of 0.009 and 0.019 $\mathrm{mg} / \mathrm{kg}$, respectively.

On contrast, lower levels of some organochlorine insecticide residues were obtained by Aksoy et al. (2013) in Turkey who could not detect DDT, $\alpha$ $\mathrm{HCH}$, Lindane, Aldrin or $\mathrm{HCB}$ and Salem et al. (2009) in Jordan also could not detect $\alpha-\mathrm{HCH}, \gamma$ $\mathrm{HCH}$, Aldrin, Heptachlor or HCB and this may be attributed to presence of these residues at very low values below the detection limits.

For quantitative risk assessment, the HQ and the mean daily intake from consumption of $8 \mathrm{~g}$ butter/day in Table (6) for $\alpha-\mathrm{HCH}, \beta-\mathrm{HCH}, \gamma-\mathrm{HCH}$, HCB, Aldrin, Heptachlor, Chlordane, total DDT, Endrin and Methoxychlor were 0 and0, 0.00002 and $0.00000032,0.0001$ and 0.00004, 0 and0, 0.000009 and $0.00000006,0.00004$ and 0.0000003 , 0.0000018 and $0.00000006,0.000001$ and $0.0000008,0.000003$ and $0.00000004 \& 0$ and 0 , respectively, It is cleared that none of the obtained results exceeded 0.2 for HQ that indicated safety results according to CCME (1996) and also none of the obtained results exceeded the ADI of 0.07, 0.021, $0.35,0.042,0.007,0.007,0.035,0.7,0.014$ and 7 $\mathrm{mg} / 70 \mathrm{~kg}$ person for $\alpha-\mathrm{HCH}, \beta-\mathrm{HCH}, \gamma-\mathrm{HCH}, \mathrm{HCB}$, Aldrin, Heptachlor, Chlordane, total DDT, Endrin and Methoxychlor respectively as recommended by Codex Alimentarius Commission (2014).

By comparing the obtained results with the MRLs adopted by Codex Alimentarius Commission (2014) we found that all the detected values were below the recommended MRLs except $\gamma-\mathrm{HCH}$ exceeded the MRL in two samples and $\beta-\mathrm{HCH}$ in one sample that may be attributed to persistent nature and bio accumulation of these compounds in the fatty foods (Aman and Bluthgen, 1997).

From the public health point of view, we observed that despite the low percentage $4 \%(3 / 75)$ of samples exceeding the MRLs in this study, these compounds represent a potential risk to human health because of their accumulation properties in human fat tissue and presence of different residues which may be synergize together and cause health hazards to human beings. The overall results from this study showed that milk and dairy products are an important route for OCPs since they contained high fat content and consumption of these products contribute in high degree to human exposure to organochlorine insecticides.

In our study there are three butter samples contained $\alpha-\mathrm{HCH}$ and $\gamma-\mathrm{HCH}$ above the recommended MRL that is considered highly dangerous because $\mathrm{HCH}$ isomers were considered as liver tumors producer according to Agency for Toxic Substances and Disease Registry (ATSDR) (1997) and U.S Environmental Protection Agency (1997).

Periodical surveys and studies for detection of organochlorine insecticides to estimate the state of food and environmental contamination with such compounds are recommended with Application of prompt regulatory actions to prevent possible illegal use of organochlorine insecticides in Egypt.

\section{REFERENCES}

Abd El-Aziz, A.R. (2005): Detection of pesticide residues in milk and some dairy products. $\mathrm{Ph}$. D thesis, Zagazig Uni., Faculty of Vet. Med., Food Control Department.

Ahmed, N.S. and Zaki, E.M. (2009): Detection of Some Organochlorine Pesticides in raw Milk in Giza Governorate. Journal of Applied Sciences Research, 5(12) 2520-2523.

Aksoy, A.; Dervisoglu, M.; Guvenc, D.; Gul, O.; Yazici, F. and Atmaca, E. (2013): Levels of Organochlorine Pesticide Residues in Butter Samples Collected from the Black Sea Region of Turkey. J. Bulletin of Environmental Contamination and Toxicology 90 (1) 110-115.

Aman, I.M. and Bluthgen, A. (1997): Occurrence of residues of organochlorine pesticides and polychlorinated biphenyls in milk and dairy products from Egypt. J. Milchwissenschaft. 52 (7) 394-399. 
Amr, M.M. (1999): Pesticide monitoring and its health problems in Egypt, a Third World country. J. ToxicolLett. 107(1-3): 1-13.

Agency for Toxic Substances and Disease Registry (ATSDR) (1997): Toxicological Profile for Alpha-, Beta-, Gamma-, and DeltaHexachlorocyclohexane. Draft for Public Comment. U.S. Public Health Service, U.S. Department of Health and Human Services, Atlanta, GA.

Avancini, R.M.; Silva, I.S.; Rosa, A.C.S.; Sarcinelli, P.N. and Mesquita, S.A. (2012): Organochlorine compounds in bovine milk from the state of Mato Grosso do Sul - Brazil. J. Chemosphere .10.069.

Bulut, S.; Akkaya, L.; Gök, V. and Konuk, M. (2011):Organochlorine pesticide (OCP) residues in cow's, buffalo's, and sheep's milk from Afyonkarahisar region, Turkey. J. Environ Monit. Assess. 181(1-4) 555-62.

CCME (Canadian Council of Ministers of the Environment) (1996): A Framework for Ecological Risk Assessment: General Guidance. Winnipeg, MB.

Chiş, A.; Horga, C. and Bara, V. (2008): Calculations regarding the organochlorine pesticides contamination in some sour cream types from the Bihor country. J. Bulletin UASVM, Agriculture 65(2).

Codex Alimentarius Commission (2014): Codex committee on pesticide residues. $37^{\text {th }}$ session, Geneva.

Darko, G. and Acquaah, S.O.(2008): Levels of organochlorine pesticides residues in dairy products in Kumasi, Ghana. J. Chemosphere (71) 294-298.

El-Amine, M.; David, M.; Sebastien, F.; Caroline, J.; Ramaroson, A. and Yves, M. (2013): Plasmatic concentration

of organochlorinelindane acts as metabolic disruptors in HepG2 liver cell line by inducing mitochondrial disorder. J. Toxicology and Applied Pharmacology. 272(2) 325-334.

El-Talawy, M.F. (2010): A study of pesticide residues in milk and some dairy products. $\mathrm{Ph}$. D thesis, Benha Uni., Fac. of Vet. Med., Food Control Department.

Gutterrez, R.; Ortiz, R.; Vega, S.; Schettino, B.; Ramirez, M.L. and Perez, J.J. (2013): Residues levels of organochlorine pesticide in cow's milk from industrial farms in Hidalgo, Mexico. J. Environmental Science and Health, Part B48, 935-940.

Heck, M.C.; Santos, J.S.; BoguszTunior, S.; Costabeber, I. and Emmanelli, T. (2007): Estimation of children exposure to organochlorine compounds through milk in Rio Grando Do Sul, Brazil. J. Food Chem. 102, 288-294.
Joe Thornton (2000): Pandora's Poison: Chlorine, Health, and a New Environmental Strategy. $2^{\text {nd }}$ edition ISBN 0-262-20124-0.

Kampire, E.; Kiremire, B.T.; Nyanzi, S.A. and Kishimba, M. (2011): Organochlorine pesticide in fresh and pasteurized cow's milk, Kampala markets. J. Chemosphere 84: 923 927.

Kotinagu, K. and Krishnaiah, N. (2015): Organochlorine and organophosphorus pesticide residues in fodder and milk samples along Musi River belt, India. J. Vet. World 8(4) 545-550.

Mukherjee, I. and Gopal, M. (1993): Organochlorine pesticide residues in dairy milk in and around Delhi. J. of the Association of Analytical Chemistry International. 72, 283-286.

Muntean, N.; Jermini, M.; Small, I.; Falzon, D.; Migliorati, G.; Scortichini, G.; Anklam, E.; Niyazmatov, B. and Bahkridinov, S. (2003) : Assessment of Dietary Exposure to Some Persistent Organic Pollutants in the Republic of Karakalpakstan of Uzbekistan. J. Environ Health Perspect. 111(10) 1306-1311.

Pandit, G.G.; Sharma, S.; Srivastava, P.K. and Sahu, S.K. (2002): Persistent organochlorine pesticide residues in milk and dairy products in India. J. Food Addit. Contam. Feb.; 19 (2): 153-157.

Prachar, V.; Veningerova, M.; Uhnak, J. and Pribela, A. (1995): Persistent organochlorine compounds in cow's milk and butter. J. Fresenius Environmental Bulletin; 4(7):413417. 22.

Ranganathan, Y.; Hulová, I. and Macák, J. (2014): Multi residue screening of pesticides and their recovery from fatty food matrices using the quechers method. Journal of International Scientific Publications: Agriculture and Food, (2) 1314-8591.

Ruth Stringer and Paul Johnston (2002): Chlorine and the Environment: An Overview of the Chlorine Industry. ISBN 978-90-481-5645-0.

Salem, N.M.; Ahmad, R. and Estaitieh, H. (2009): Organochlorine pesticide residues in dairy products in Jordan. J. Chemosphere (77) 673678.

Schuh, R.A.; Richardson, J.R.; Gupta, R.K.; Flaws, J.A. and Fiskum, G. (2009): Effects of the organochlorine pesticide methoxychlor on dopamine metabolites and transporters in the mouse brain. J. Neurotoxicology. 30(2) 274280.

Shaker, E.M. and Elsharkawy, E.E. (2015): Organochlorine and Organophosphorus Pesticide Residues in Raw Buffalo Milk from Agroindustrial areas in Assiut, Egypt. J. Dairy, Vet. \& Animal Research 2 (5).

U.S. Environmental Protection Agency. (1997): Health Effects Assessment Summary 
Tables. FY 1997 Update. Solid Waste and Emergency Response, Office of Emergency and Remedial Response, Cincinnati, $\mathrm{OH}$. EPA/540/R-97-036.

Waliszewski, S.M.; Pardio, V.T.; Chantiri, J.N.; Rivera, J. and Aguirre, A.A. (1997). Organochlorine pesticide residues in cow's milk and butter in Mexico. Science of the total Environment 208: 127-132.

Waliszewski, S.M.; Villalobos-Pietrini, R.; GomezArroyo, S. and Infanzon, R.M. (2003): Persistent organochlorine pesticides in Mexican butter. J. Food Additives and
Contaminants, 20 (4) 361-367.

Wilson, W.W.; Onyenwe, W.; Bradner, J.M.; Nennig, S.E. and Caudle, W.M. (2014): Developmental exposure to the organochlorine insecticide endosulfan alters expression of proteins associated with neurotransmission in the frontal cortex. J. Synapse. 68(11) 485-497.

Witczak, A. and Abdel-Gawad, H. (2014): Assessment of health risk from organochlorine pesticides residues in high-fat spreadable foods produced in Poland. J. Environ Sci. Health B. 49(12) 917-28.

\section{بقايا بعض المبيدات الحشرية في اللبن الخام والقشدة والزبد في محافظة بني سويف \\ جمال محمد حسن ، سعدية طلمي حسين الثناوي ، أبويكر رفاعي ، محمد ربيع}

